\title{
Risk Analysis and Epidemiology: The 2006 WHO Guidelines for the Safe Use of Wastewater in Agriculture
}

\author{
Duncan Mara and Robert Bos ${ }^{1}$
}

\begin{abstract}
This chapter reviews the required pathogen reductions recommended in the 2006 WHO Guidelines for the Safe Use of Wastewater, Excreta and Greywater in agriculture, which are based on a tolerable additional burden of disease of $\leq 10^{-6}$ Disability-Adjusted Life Year (DALY) loss per person per year. The quantitative microbial risk-analysis technique, combined with 10,000-trial Monte Carlo risk simulations, is detailed here and the resulting estimates of median risk for various levels of pathogen reduction for exposure via restricted and unrestricted irrigation are also presented. This enables the selection of suitable combinations of pathogen reduction measures (wastewater treatment and post-treatment health-protection measures) to be selected, so that the resulting additional burden of disease does not exceed $10^{-6}$ DALY loss per person per year.
\end{abstract}

\section{INTRODUCTION}

The World Health Organization published the third edition of its Guidelines for the safe use of wastewater in agriculture in September 2006 (WHO, 2006). These 
differed from the second edition of the Guidelines (WHO, 1989) principally as follows:

- The use of a risk-based approach to estimate the required reductions of viral, bacterial and protozoan pathogens.

- To protect the health of those working, or otherwise exposed, in wastewaterirrigated fields (i.e. restricted irrigation), the required pathogen reductions are to be achieved only by wastewater treatment.

- To protect the health of those consuming wastewater-irrigated food crops (i.e. unrestricted irrigation), the required pathogen reductions can be achieved by a suitable combination of wastewater treatment (commonly to the level required for restricted irrigation) and post-treatment health-protection control measures such as outlined below.

The 2006 Guidelines are essentially a code of good management practices to ensure that, when wastewater is used in agriculture (mainly for irrigating crops, including food crops that are or may be eaten uncooked), it is used safely and with minimal risks to health. They are therefore much more than a set of guideline values. However, in practice wastewater treatment and reuse engineers need to know how to use the recommendations in the Guidelines to design wastewater reuse systems that do not adversely affect public health. This means that they have to understand in detail the basis of the Guidelines so that the wastewater reuse systems they design are safe.

There are two broad groups of wastewater-related diseases relevant in the agricultural use of wastewater (Table 3.1) that are considered in the Guidelines and in this chapter:

- viral, bacterial and protozoan diseases, for which the health risks are determined by quantitative microbial risk assessment (QMRA);

- helminthic diseases, for which the Guidelines set a guideline value on the basis of epidemiological studies.

The basis of human health protection in the Guidelines is that the additional disease burden due to viral, bacterial and protozoan diseases which results from working in wastewater-irrigated fields or consuming wastewater-irrigated crops should not exceed $10^{-6}$ DALY loss per person per year (see Box 3.1). This level of health protection was used by WHO in its 2004 Guidelines on drinking-water quality (WHO, 2004) and thus the health risks resulting from wastewater use in agriculture are the same as those from drinking fully treated drinking water - this is basically what consumers want as they expect the food they eat to be as safe as the water they drink.

For the viral, bacterial and protozoan diseases this tolerable additional disease burden of $10^{-6}$ DALY loss pppy is 'translated' into tolerable disease and infection risks as follows: 
Table 3.1 Classification of diseases relevant in wastewater-irrigated agriculture

\begin{tabular}{|c|c|c|c|}
\hline Category & $\begin{array}{l}\text { Environmental transmission } \\
\text { features }\end{array}$ & $\begin{array}{l}\text { Major examples of } \\
\text { infection }\end{array}$ & $\begin{array}{l}\text { Exposure } \\
\text { groups in urban } \\
\text { agriculture and } \\
\text { relative infection } \\
\text { risks }\end{array}$ \\
\hline $\begin{array}{l}\text { Non-bacterial } \\
\text { faeco-oral } \\
\text { diseases }\end{array}$ & $\begin{array}{l}\text { Non-latent }{ }^{a} \\
\text { Low to medium persistence }{ }^{b} \\
\text { Unable to multiply } \\
\text { High infectivity }\end{array}$ & $\begin{array}{l}\text { Viral: } \\
\text { Hepatitis A and E } \\
\text { Rotavirus diarrhoea } \\
\text { Norovirus diarrhoea } \\
\text { Protozoan: } \\
\text { Amoebiasis } \\
\text { Crystosporidiasis } \\
\text { Giardiasis } \\
\text { Cyclosporiasis }\end{array}$ & $\begin{array}{l}\text { Fieldworkers: }+^{C} \\
\text { Consumers: }+++\end{array}$ \\
\hline $\begin{array}{l}\text { Bacterial faeco- } \\
\text { oral diseases }\end{array}$ & $\begin{array}{l}\text { Non-latent } \\
\text { Medium to high persistence } \\
\text { Able to multiply } \\
\text { Medium to low infectivity }\end{array}$ & $\begin{array}{l}\text { Campylobacteriosis } \\
\text { Cholera } \\
\text { Pathogenic Escherichia } \\
\text { coli infection } \\
\text { Salmonellosis } \\
\text { Shigellosis }\end{array}$ & $\begin{array}{l}\text { Fieldworkers: + } \\
\text { Consumers: }+++\end{array}$ \\
\hline Geohelminthiases & $\begin{array}{l}\text { Latent } \\
\text { Very persistent } \\
\text { Unable to multiply } \\
\text { Very high infectivity }\end{array}$ & $\begin{array}{l}\text { Ascariasis } \\
\text { Hookworm infection } \\
\text { Trichuriasis }\end{array}$ & $\begin{array}{l}\text { Fieldworkers: } \\
+++ \\
\text { Consumers: +++ }\end{array}$ \\
\hline
\end{tabular}

+++ high risk; ++ medium risk; + low risk (These risks refer to the use of untreated wastewaters; treatment and posttreatment health-protection control measures can reduce these risks to the tolerable level of $\leq 10^{-3}$ per person per year, as discussed below.)

a Latency is the length of time outside a human host required for the pathogen to become infective.

bersistence is the length of time that the pathogen can survive in the environment outside a human host.

cNote that fieldworkers are commonly also consumers.

Source: Feachem et al. (1983)

$$
\text { Tolerable disease risk pppy }=\frac{\text { Tolerable DALY loss pppy (i.e., } \left.10^{-6}\right)}{\text { DALY loss per case of disease }}
$$$$
\text { Tolerable infection risk pppy }=\frac{\text { Tolerable disease risk pppy }}{\text { Disease/infection ratio }}
$$

Three 'index' pathogens were selected: rotavirus, viral pathogen; Campylobacter, a bacterial pathogen; and Cryptosporidium, a protozoan pathogen. Table 3.2 gives the DALY losses per case of rotavirus diarrhoea, campylobacteriosis and cryptosporidiosis and the corresponding disease/infection ratios. (A better index viral pathogen would now be norovirus, for which dose-response data have recently become available. See Chapter 5.) 


\section{Box 3.1 DisABILITY-ADJUSTED LIFE YEARS (DALYS)}

DALYs are a measure of the health of a population or burden of disease due to a specific disease or risk factor. DALYs attempt to measure the time lost because of disability or death from a disease compared with a long life free of disability in the absence of the disease. DALYs are calculated by adding the years of life lost to premature death (YLL) to the years lived with a disability (YLD). Years of life lost are calculated from age-specific mortality rates and the standard life expectancies of a given population. YLD are calculated from the number of cases multiplied by the average duration of the disease and a severity factor ranging from 1 (death) to 0 (perfect health) based on the disease (e.g. watery diarrhoea has a severity factor from 0.09 to 0.12 depending on the age group) (Murray and Lopez, 1996; Prüss and Havelaar, 2001).

DALYs are an important tool for comparing health outcomes because they account for not only acute health effects but also for delayed and chronic effects, including morbidity and mortality (Bartram et al., 2001). Thus, when risk is described in DALYs, different health outcomes (e.g., stomach cancer and giardiasis) can be compared and riskmanagement decisions prioritized. Thus the DALY loss per case of campylobacteriosis in Table 3.1 includes the appropriate allowance for the occurrence of Guillain-Barré syndrome (which is an inflammatory disorder of the peripheral nerves, which may lead to paralysis, and which occurs in around 1 in 1000 cases of campylobacteriosis).

The tolerable additional disease burden of $10^{-6} \mathrm{DALY}$ loss adopted in the Guidelines means that a city of 1 million people collectively suffers the loss of one DALY per year. The highest DALY loss per case of diarrhoeal disease in Table 3.2 is $2.6 \times 10^{-2}$, for rotavirus disease in developing countries. Assuming that the recommendations in the Guidelines are completely followed, this means that the tolerable number of cases of rotavirus disease, caused by the consumption of wastewater-irrigated food, in this city of 1 million people in a developing country is:

$$
\frac{1 \text { DALY loss per year }}{2.6 \times 10^{-2} \text { DALY loss per case }}=38 \text { cases per year }
$$

The chance of an individual living in this city becoming ill with rotavirus diarrhoea in any one year is $\left(38 \times 10^{-6}\right)-$ i.e., $3.8 \times 10^{-5}$, which is the tolerable rotavirus disease risk per person per year in developing countries, as determined in Table 3.2.

From the data in Table 3.2 a 'design' value of $10^{-4}$ pppy was chosen for the tolerable risk of rotavirus disease and $10^{-3}$ pppy for the corresponding tolerable rotavirus infection risk. The former is extremely safe as it is three to four orders of magnitude lower than the actual incidence of diarrhoeal disease in the world (Table 3.3).

\section{QUANTITATIVE MICROBIAL RISK ASSESSMENT}

The Guidelines adopted a standard QMRA approach (Haas et al., 1999) to risk analysis combined with 10,000-iteration Monte Carlo simulations (Mara et al., 2007). The basic equations are: 
Table 3.2 DALY losses, disease risks, diseaselinfection ratios and tolerable infection risks for rotavirus, Campylobacter and Cryptosporidium

\begin{tabular}{lcccc}
\hline Pathogen & $\begin{array}{c}\text { DALY loss } \\
\text { per case of } \\
\text { disease }\end{array}$ & $\begin{array}{c}\text { Tolerable } \\
\text { disease risk pppy } \\
\text { equivalent to 10 } \\
\text { DALY loss pppy }\end{array}$ & $\begin{array}{c}\text { Disease/ } \\
\text { infection } \\
\text { ratio }\end{array}$ & $\begin{array}{c}\text { Tolerable } \\
\text { infection risk } \\
\text { pppy }^{b}\end{array}$ \\
\hline Rotavirus: (1) IC C $^{\mathrm{b}}$ & $1.4 \times 10^{-2}$ & $7.1 \times 10^{-5}$ & $0.05^{d}$ & $1.4 \times 10^{-3}$ \\
Rotavirus: (2) DC & $2.6 \times 10^{-2}$ & $3.8 \times 10^{-5}$ & $0.05^{d}$ & $7.7 \times 10^{-4}$ \\
Campylobacter & $4.6 \times 10^{-3}$ & $2.2 \times 10^{-4}$ & 0.7 & $3.1 \times 10^{-4}$ \\
Cryptosporidium & $1.5 \times 10^{-3}$ & $6.7 \times 10^{-4}$ & 0.3 & $2.2 \times 10^{-3}$ \\
\hline
\end{tabular}

aTolerable disease risk $=10^{-6}$ DALY loss per person per year (pppy) $\div$ DALY loss per case of disease.

${ }^{b}$ Tolerable infection risk $=$ disease risk $\div$ disease/infection ratio.

${ }^{\mathrm{I} C}$, industrialized countries; DC, developing countries.

${ }^{d}$ For developing counties the DALY loss per rotavirus death was reduced by 95 per cent to discount deaths occurring in children under the age of two who are not exposed to wastewater-irrigated foods. The disease/infection ratio for rotavirus is low as immunity is mostly developed by the age of three.

Source: DALY values from Havelaar and Melse (2003)

Table 3.3 Diarrhoeal disease (DD) incidence pppy in 2000 by region and age

\begin{tabular}{lccc}
\hline Region & $\begin{array}{c}\text { DD incidence } \\
\text { in all ages }\end{array}$ & $\begin{array}{c}\text { DD incidence } \\
\text { in 0-4 year olds }\end{array}$ & $\begin{array}{c}\text { DD incidence } \\
\text { in 5-80+ year olds }\end{array}$ \\
\hline Industrialized countries & 0.2 & $0.2-1.7$ & $0.1-0.2$ \\
Developing countries & $0.8-1.3$ & $2.4-5.2$ & $0.4-0.6$ \\
Global average & 0.7 & 3.7 & 0.4 \\
\hline
\end{tabular}

Source: Mathers et al. (2002)

Exponential dose-response model (for Cryptosporidium):

$$
\mathrm{P}_{\mathrm{I}}(d)=1-\exp (-r d)
$$

Beta-Poisson dose-response model (for rotavirus and Campylobacter):

$$
\mathrm{P}_{\mathrm{I}}(d)=1-\left[1+\left(d / N_{50}\right)\left(2^{1 / \alpha}-1\right)\right]^{-\alpha}
$$

Annual risk of infection:

$$
\mathrm{P}_{\mathrm{I}(\mathrm{A})}(d)=1-\left[1-\mathrm{P}_{\mathrm{I}}(d)\right]^{n}
$$

$\mathrm{P}_{\mathrm{I}}(d)$ is the risk of infection in an individual exposed to a single pathogen dose $d$ - i.e., the number of pathogens ingested on any one occasion; $\mathrm{P}_{\mathrm{I}(\mathrm{A})}(d)$ is the annual risk of infection in an individual from $n$ exposures per year to the single pathogen dose $d ; N_{50}$ is the median infective dose; and $\alpha$ and $r$ are pathogen 'infectivity 
constants' - for rotavirus $N_{50}=6.17$ and $\alpha=0.253$, for Campylobacter $N_{50}=896$ and $\alpha=0.145$ and for Cryptosporidium $r=0.0042$ (Haas et al., 1999).

In practice Equations 3.4, 3.5 and 3.6 are used as follows:

- $\mathrm{P}_{\mathrm{I}(\mathrm{A})}(d)$ in Equation 3.4 is set equal to $10^{-3}$ pppy (the tolerable rotavirus infection risk).

- The number of days of exposure ( $n$ in Equation 3.6) is determined (or selected) - e.g. for lettuce consumption on alternate days $n=365 / 2$.

- $\mathrm{P}_{\mathrm{I}}(d)$ is then calculated from Equation 3.6 (e.g. for $n=365 / 2, \mathrm{P}_{\mathrm{I}}(d)=5.5 \times$ $10^{-6}$ per person per exposure).

- For this value of $\mathrm{P}_{\mathrm{I}}(d) d$ is calculated from either Equation 3.4 or Equation 3.5 .

- This dose $d$ is the number of pathogens ingested with the lettuce (or other crop) and is assumed to be in whatever volume of treated wastewater that remains on the lettuce (or other crop) after irrigation - for example, Shuval et al. (1997) found $11 \mathrm{ml}$ to remain on $100 \mathrm{~g}$ of lettuce.

- This pathogen count (e.g. $d$ per $11 \mathrm{ml}$ ) is expressed per litre and, knowing the pathogen count per litre of untreated wastewater, the required log reduction (actually the required $\log _{10}$ reduction) of the pathogen is determined.

This required log pathogen reduction is achieved by a combination of wastewater treatment and the post-treatment health-protection control measures detailed in Table 3.4.

Table 3.4 Post-treatment health-protection control measures and associated pathogen reductions

\begin{tabular}{|c|c|c|}
\hline Control measure & $\begin{array}{l}\text { Pathogen } \\
\text { reduction } \\
\text { (log units) }\end{array}$ & Notes \\
\hline Drip irrigation & $2-4$ & $\begin{array}{l}2 \text { log unit reduction for low-growing crops, and } \\
4 \text { log unit reduction for high-growing crops. }\end{array}$ \\
\hline Pathogen die-off & $\begin{array}{l}0.5-2 \\
\text { per day }\end{array}$ & $\begin{array}{l}\text { Die-off after last irrigation before harvest } \\
\text { (value depends on climate, crop type, etc.). }\end{array}$ \\
\hline Produce-washing & 1 & $\begin{array}{l}\text { Washing salad crops, vegetables and fruit with clean } \\
\text { water. }\end{array}$ \\
\hline Produce disinfection & 3 & $\begin{array}{l}\text { Washing salad crops, vegetables and fruit with a weak } \\
\text { disinfectant solution and rinsing with clean water. }\end{array}$ \\
\hline Produce peeling & 2 & Fruits, root crops. \\
\hline
\end{tabular}

Source: Produce disinfection reduction figure from Amoah et al. (2007) 


\section{Monte Carlo risk simulations}

There is commonly some degree of uncertainty about the values of the parameters used to determine required log pathogen reductions - for example, it is unlikely that exactly $11 \mathrm{ml}$ of wastewater is always left on $100 \mathrm{~g}$ of lettuce after irrigation. Therefore, in order to take this uncertainty into account, it is better to assign a range of values to each parameter (e.g., $10-15 \mathrm{ml}$ of wastewater remaining on $100 \mathrm{~g}$ of lettuce after irrigation), rather than a single 'fixed' value (e.g. exactly $11 \mathrm{ml}$ ), although a fixed value can be assigned to any parameter if so wished. A computer program then selects at random a value for each parameter from the range of values specified for it and determines the resulting risk. ${ }^{2}$ The program repeats this process a large number of times (commonly for a total of 10,000 times) and then determines the median annual infection risk. The large number of repetitions removes some of the uncertainty associated with the parameter values and makes the results generated by multi-trial Monte Carlo simulations much more robust, although of course they are only as good as the assumptions made. Chapter 5 describes an improved method of determining annual risks of infection.

\section{RESTRICTED IRRIGATION}

The exposure scenario developed in the Guidelines for restricted irrigation is the involuntary ingestion of soil particles by those working, or by young children playing, in wastewater-irrigated fields. This is a likely scenario as wastewatersaturated soil would contaminate the workers' or children's fingers and so some pathogens could be transmitted to their mouths and hence ingested. The quantity of soil involuntarily ingested in this way has been reported (but not specifically for this restricted-irrigation scenario) as up to $100 \mathrm{mg}$ per person per day of exposure (Haas et al., 1999; WHO 2001). Two sub-scenarios were investigated: (a) highly mechanized agriculture and (b) labour-intensive agriculture. The former represents exposure in industrialized countries where farm workers typically plough, sow and harvest using tractors and associated equipment and can be expected to wear gloves and be generally hygiene-conscious when working in wastewater-irrigated fields. The latter represents farming practices in developing countries in situations where tractors are not used and gloves (and often footwear) are not worn, and where hygiene is commonly not promoted.

\section{Labour-intensive agriculture}

The results of the Monte Carlo-QMRA risk simulations are given in Table 3.5 for various wastewater qualities (expressed as single log ranges of $E$. coli numbers per $100 \mathrm{ml}$ ) and for 300 days' exposure per year (the footnote to Table 3.5 gives the range of values assigned to each parameter). It can be seen that the median 
Table 3.5 Restricted irrigation: median infection risks from ingestion of wastewater-contaminated soil in labour-intensive agriculture with exposure for 300 days per year

\begin{tabular}{lccc}
\hline Soil quality & \multicolumn{3}{c}{$\begin{array}{c}\text { Median infection risk pppy } \\
\text { (E. coli per 100g) }\end{array}$} \\
\hline $10^{7}-10^{8}$ & Rotavirus & 0.50 & $1.4 \times 10^{-2}$ \\
$10^{6}-10^{7}$ & 0.99 & $6.7 \times 10^{-2}$ & $1.4 \times 10^{-3}$ \\
$10^{5}-10^{6}$ & 0.88 & $7.3 \times 10^{-3}$ & $1.4 \times 10^{-4}$ \\
$10^{4}-10^{5}$ & 0.19 & $7.0 \times 10^{-4}$ & $1.3 \times 10^{-5}$ \\
$10^{3}-10^{4}$ & $2.0 \times 10^{-2}$ & $6.1 \times 10^{-5}$ & $1.4 \times 10^{-6}$ \\
$100-1000$ & $1.8 \times 10^{-3}$ & $5.6 \times 10^{-6}$ & $1.4 \times 10^{-7}$ \\
\hline
\end{tabular}

aEstimated by 10,000 Monte Carlo simulations. Assumptions: 10-100mg soil ingested per person per day for 300 days per year; 0.1-1 rotavirus and Campylobacter, and 0.01-0.1 Cryptosporidium oocyst, per $10^{5}$ E. coli; $N_{50}=6.7 \pm 25 \%$ and $\alpha=0.253 \pm 25 \%$ for rotavirus; $N_{50}=896 \pm 25 \%$ and $\alpha=0.145 \pm 25 \%$ for Campylobacter; $r=0.0042 \pm 25 \%$ for Cryptosporidium. No pathogen die-off (taken as a worst case scenario).

${ }^{b}$ The wastewater quality is taken to be the same as the soil quality - i.e. the soil is assumed, as a worst case scenario, to be saturated with the wastewater.

rotavirus infection risk is $10^{-3}$ pppy for a wastewater quality of $10^{3}-10^{4} \mathrm{E}$. coli per $100 \mathrm{ml}$. Thus, the tolerable rotavirus infection risk of $10^{-3}$ pppy is achieved by a $4 \log$ unit reduction - i.e. from $10^{7}-10^{8}$ to $10^{3}-10^{4}$ E. coli per $100 \mathrm{ml}$. The table also shows that the Campylobacter and Cryptosporidium infection risks are all lower than those for rotavirus.

\section{Highly mechanized agriculture}

The simulated risks for various wastewater qualities and for 100 days' exposure per year are given in Table 3.6, which shows that a $3 \log$ unit reduction, from $10^{7}-10^{8}$ to $10^{4}-10^{5}$ E. coli per $100 \mathrm{ml}$, is required to achieve the tolerable rotavirus infection risk of $10^{-3}$ pppy.

\section{UNRESTRICTED IRRIGATION}

The exposure scenarios used in the Guidelines for unrestricted irrigation are the consumption of wastewater-irrigated lettuce (Shuval et al., 1997) and the consumption of wastewater-irrigated onions (a leaf and a root vegetable, respectively).

\section{Risk simulations}

For unrestricted irrigation a slightly different approach was adopted. The QMRAMonte Carlo program determined the required log rotavirus reductions for various 
Table 3.6 Restricted irrigation: median infection risks from ingestion of wastewater-contaminated soil in highly mechanized agriculture with exposure for 100 days per year ${ }^{a}$

\begin{tabular}{lccc}
\hline $\begin{array}{l}\text { Soil quality } \\
(\text { E. coli per 100g) })^{b}\end{array}$ & Rotavirus & $\begin{array}{c}\text { Median infection risk pppy } \\
\text { Campylobacter }\end{array}$ & Cryptosporidium \\
\hline $10^{6}-10^{7}$ & $6.8 \times 10^{-2}$ & $1.9 \times 10^{-3}$ & $4.7 \times 10^{-5}$ \\
$10^{5}-10^{6}$ & $6.7 \times 10^{-3}$ & $1.9 \times 10^{-4}$ & $4.6 \times 10^{-6}$ \\
$10^{4}-10^{5}$ & $6.5 \times 10^{-4}$ & $2.3 \times 10^{-5}$ & $4.6 \times 10^{-7}$ \\
$10^{3}-10^{4}$ & $6.8 \times 10^{-5}$ & $2.4 \times 10^{-6}$ & $5.0 \times 10^{-8}$ \\
$100-1000$ & $6.3 \times 10^{-6}$ & $2.2 \times 10^{-7}$ & $\leq 1 \times 10^{-8}$ \\
\hline
\end{tabular}

${ }^{a}$ Estimated by 10,000 Monte Carlo simulations. Assumptions: $1-10 \mathrm{mg}$ soil ingested per person per day for 100 days per year; 0.1-1 rotavirus and Campylobacter, and 0.01-0.1 Cryptosporidium oocyst, per 105 E. coli; $N_{50}=6.7 \pm 25 \%$ and $\alpha=0.253 \pm 25 \%$ for rotavirus; $N_{50}=896 \pm 25 \%$ and $\alpha=0.145 \pm 25 \%$ for Campylobacter $r=0.0042 \pm 25 \%$ for Cryptosporidium. No pathogen die-off (taken as a worst case scenario).

${ }^{b}$ The wastewater quality is taken to be the same as the soil quality - i.e., the soil is assumed, as a worst case scenario, to be saturated with the wastewater.

Table 3.7 Unrestricted irrigation: required pathogen reductions for various levels of tolerable risk of rotavirus infection from the consumption of wastewater-irrigated lettuce and onions ${ }^{a}$

\begin{tabular}{lcc}
\hline $\begin{array}{l}\text { Tolerable level of } \\
\text { rotavirus infection } \\
\text { risk (pppy) }\end{array}$ & \multicolumn{2}{c}{$\begin{array}{c}\text { Corresponding required level of rotavirus } \\
\text { reduction (log units) }\end{array}$} \\
\cline { 2 - 3 } & Lettuce & Onions \\
\hline $10^{-2}$ & 5 & 6 \\
$10^{-3}$ & 6 & 7 \\
$10^{-4}$ & 7 & 8 \\
\hline
\end{tabular}

aEstimated by 10,000 Monte Carlo simulations. Assumptions: $100 \mathrm{~g}$ lettuce and onions eaten per person per two days; $10-15 \mathrm{ml}$ and $1-5 \mathrm{ml}$ wastewater remaining after irrigation on lettuce and onions, respectively; $0.1-1$ and rotavirus per $10^{5}$ E. coli; $N_{50}=6.17 \pm 25 \%$ and $\alpha=0.253 \pm 25 \%$. No pathogen die-off.

levels of tolerable rotavirus annual infection risk. The results, given in Table 3.7, show that, for the tolerable rotavirus infection risk of $10^{-3}$ pppy, the required pathogen reductions are $6 \log$ units for non-root crops and 7 log units for root crops. The table also shows that the consumption of root crops requires a 1 log unit pathogen reduction greater than the consumption of non-root crops and that the required pathogen reductions change by an order of magnitude with each orderof-magnitude change in tolerable risk.

This 6-7 log unit reduction for unrestricted irrigation is best achieved by a 3-4 log unit reduction by wastewater treatment, as required for restricted irrigation, supplemented by a 2-4 log unit reduction from post-treatment health-protection control measures (Table 3.4). These post-treatment health-protection control measures are extremely reliable: in essence they always occur. 


\section{EPIDEMIOLOGICAL VERIFICATION OF THE QMRA APPROACH}

Mara et al. (2007) used the field data reported by Blumenthal et al. (2003) on diarrhoeal disease incidences amongst fieldworkers and consumers in Mezquital Valley, Mexico, to obtain QMRA estimates of rotavirus infection risks in the fivemonth dry season. It was found that, provided the assumptions used in the QMRAMonte Carlo risk simulations closely reflected field conditions, the agreement between the observed incidences of diarrhoeal disease and the simulated rotavirus infection risk was very close for both fieldworkers and consumers (Table 3.8).

\section{HELMINTH EGGS}

The recommendation in the Guidelines is that wastewater used in agriculture should contain $\leq 1$ helminth egg per litre. The helminths referred to here are the human intestinal nematodes: Ascaris lumbricoides (the human roundworm), Trichuris trichiura (the human whipworm), and Ancylostoma duodenale and Necator americanus (the human hookworms); details of the diseases they cause and their life cycles are given in Feachem et al. (1983).

This recommendation is the same as was made in the 1989 Guidelines (WHO, 1989), but with two important differences: it is now based on epidemiological evidence which shows that $\leq 1$ egg per litre protects adults but not children under 15 (Blumenthal et al., 2000); and when children under the age of 15 are exposed, additional control measures are needed, such as regular deworming (by their parents or at school).

Chapter 5 details a QMRA-Monte Carlo method for estimating Ascaris infection risks.

Table 3.8 Comparison between observed incidences of diarrhoeal disease and estimated rotavirus infection risks in Mezquital Valley, Mexico

\begin{tabular}{lccc}
\hline $\begin{array}{l}\text { Irrigation } \\
\text { scenario }\end{array}$ & $\begin{array}{c}\text { Wastewater quality } \\
(E . \text { coli } \\
\text { per 100ml) }\end{array}$ & $\begin{array}{c}\text { Observed diarrhoeal } \\
\text { disease incidence per } \\
\text { person per 5 months }\end{array}$ & $\begin{array}{c}\text { Estimated median } \\
\text { rotavirus infection risk per } \\
\text { person per 5 months }\end{array}$ \\
\hline $\begin{array}{l}\text { Restricted } \\
\text { irrigation }\end{array}$ & $10^{3}-10^{5}$ & 0.37 & $0.33^{a}$ \\
$\begin{array}{l}\text { Unrestricted } \\
\text { irrigation }\end{array}$ & $10^{3}-10^{5}$ & 0.38 & $0.39^{b}$ \\
\hline
\end{tabular}

${ }^{a}$ Assumptions: soil quality per $100 \mathrm{~g}$ taken as wastewater quality per $100 \mathrm{ml} ; 10-100 \mathrm{mg}$ soil ingested per person per day for 65 days in five months; $0.1-1$ rotavirus per $10^{5} \mathrm{E}$. coll; $\mathrm{ID}_{50}=6.7 \pm 25 \%$ and $\alpha=0.253 \pm 25 \%$. No pathogen die-off. ${ }^{b}$ Assumptions: $100 \mathrm{~g}$ of onions consumed per person per week for five months; $1-5 \mathrm{ml}$ wastewater remaining on $100 \mathrm{~g}$ onions after irrigation; $0.1-1$ rotavirus per $10^{5} \mathrm{E}$. coli; $0-1$ log unit rotavirus die-off between harvest and consumption; $\mathrm{ID}_{50}$ $=6.7 \pm 25 \%$ and $\alpha=0.253 \pm 25 \%$.

Source: Mara et al. (2007) 


\section{SUMMARY OF RECOMMENDATIONS IN THE GUIDELINES}

The 2006 WHO Guidelines make the following recommendations, either explicitly or implicitly:

- To protect the health of those working in wastewater-irrigated fields against excessive risks of viral, bacterial and protozoan infections, there should be a 3-4 log unit pathogen reduction, which is to be achieved by wastewater treatment.

- To protect the health of those consuming wastewater-irrigated food crops against excessive risks of viral, bacterial and protozoan infections, there should be a 6-7 log unit pathogen reduction, which is to be achieved by wastewater treatment (a 3-4 log unit reduction, as for restricted irrigation) supplemented by post-treatment health-protection control measures providing together a further 2-4 log unit pathogen reduction.

- To protect the health of those working in wastewater-irrigated fields and those consuming wastewater-irrigated food crops against excessive risks of helminthic infections, the treated wastewater should contain $\leq 1$ human intestinal nematode egg per litre.

These Guidelines are reviewed, and recommendations made for their updating, in Chapter 5.

\section{NOTES}

1 The opinions expressed in this chapter are those of the authors and do not necessarily reflect the views or policies of the World Health Organization.

2 The QMRA-Monte Carlo computer programs used for the 2006 Guidelines are available at: www.personal.leeds.ac.uk/ - cen6ddm/QMRA.html.

\section{REFERENCES}

Amoah, P., Drechsel, P., Abaidoo, R. and Klutse, A. (2007) 'Effectiveness of common and improved sanitary washing methods in selected cities of West Africa for the reduction of coliform bacteria and helminth eggs on vegetables', Tropical Medicine and International Health, no 12 (s2), pp40-50

Bartram, J., Fewtrell, L. and Stenström, T.-A. (2001) 'Harmonised assessment of risk and risk management for water-related infectious disease: An overview', in L. Fewtrell and J. Bartram (eds) Water Quality: Guidelines, Standards and Health; Assessment of Risk and Risk Management for Water-Related Infectious Disease, International Water Association (IWA) on behalf on the World Health Organization, London, pp2-16 
Blumenthal, U. J., Mara, D. D., Peasey, A., Ruiz-Palacios, G. and Stott, R. (2000) 'Guidelines for the microbiological quality of treated wastewater used in agriculture: Recommendations for revising WHO guidelines', Bulletin of the World Health Organization, vol 78, no 9, pp1104-16

Blumenthal, U. J., Peasey, A., Quigley, M. and Ruiz-Palacios, G. (2003) Risk of Enteric Infections through Consumption of Vegetables with Contaminated River Water, London School of Hygiene and Tropical Medicine, London

Feachem, R. G., Bradley, D. J., Garelick, H. and Mara, D. D. (1983) Sanitation and Disease: Health Aspects of Wastewater and Excreta Management, John Wiley \& Sons, Chichester

Haas, C. N., Rose, J. B. and Gerba, C. P. (1999) Quantitative Microbial Risk Assessment, John Wiley \& Sons, New York

Havelaar, A. H. and Melse, J. M. (2003) Quantifying Public Health Risk in the WHO Guidelines for Drinking-Water Quality: A Burden of Disease Approach, RIVM Report no 734301022/2003, Rijksinstituut voor Volksgezondheid en Milieu, Bilthoven, The Netherlands

Mara, D. D., Sleigh, P.A., Blumenthal, U. J. and Carr, R. M. (2007) 'Health risks in wastewater irrigation: Comparing estimates from quantitative microbial risk analyses and epidemiological studies', Journal of Water and Health, vol 5, no 1, pp39-50

Mathers, C. D., Stein, C., Ma Fat, D., Rao, C., Inoue, M., Tomijima, N. et al. (2002) Global Burden of Disease 2000, Version 2: Methods and Results, World Health Organization, Geneva

Murray, C. J. L. and Lopez, A. D. (1996) The Global Burden of Disease, Volume 1: A Comprehensive Assessment of Mortality and Disability from Diseases, Injuries, and Risk Factors in 1990 and Projected to 2020, Harvard University Press, Cambridge, MA

Prüss, A. and Havelaar, A. (2001) 'The Global Burden of Disease study and applications in water, sanitation, and hygiene', in L. Fewtrell and J. Bartram (eds) Water Quality: Guidelines, Standards and Health; Assessment of Risk and Risk Management for Waterrelated Infectious Disease, International Water Association (IWA) on behalf on the World Health Organization, London, pp43-59

Shuval, H. I., Lampert, Y. and Fattal, B. (1997) 'Development of a risk assessment approach for evaluating wastewater reuse standards for agriculture', Water Science and Technology, vol 35, nos 11-12, pp15-20

WHO (1989) Health Guidelines for the Use of Wastewater in Agriculture and Aquaculture, Technical Report Series no 778, World Health Organization, Geneva

WHO (2001) 'Depleted uranium: sources, exposure and health effects' (Report no WHO/SDE/PHE/01.1), World Health Organization, Geneva

WHO (2004) Guidelines for Drinking-Water Quality, 3rd ed., World Health Organization, Geneva

WHO (2006) Guidelines for the Safe Use of Wastewater, Excreta and Greywater, Volume 2: Wastewater Use in Agriculture, World Health Organization, Geneva 